\title{
EVALUATION OF PHYSICAL THERAPY EFFECTIVENESS AFTER ANTERIOR CRUCIATE LIGAMENT RECONSTRUCTION
}

\author{
Kęstutis Radžiūnas', Vytenis Trumpickas² ${ }^{2}$ Jonas Poderys $^{3}$ \\ Lithuanian University of Health Sciences, Medical Academy' ${ }^{1}$, Kaunas, Lithuania \\ Hospital of Lithuanian University of Health Sciences Kauno Klinikos', Kaunas, Lithuania \\ Lithuanian Academy of Physical Education ${ }^{3}$, Kaunas, Lithuania
}

\begin{abstract}
Research background and hypothesis. The aim of physical therapy after sports trauma is to help patients to restore physical activity as it was before injury. The participants who applied for intensive physical therapy after anterior cruciate ligament reconstructive surgery will achieve better leg muscle strength results.

Research aim was to compare the effectiveness of intensive and traditional rehabilitation of the knee extensor and flexor muscle strength after the surgery for patients after anterior cruciate ligament reconstruction.

Research methods. The method that we used was "Biodex Medical System 3 PRO" for the knee muscle strength. A total of 30 patients were enrolled in this study. The subjects were divided into two groups. The muscle strength was measured while leg was flexed and extended at the knee joint.

Research results. The research results showed that participants who received intensive physical therapy program developed better muscle strength than in standard physical therapy group. Participant's leg muscles recovered faster in intensive physical therapy group than in standard physical therapy group.

Discussion and conclusions. The participants who received physical therapy before surgery, electrostimulation and intensive physical therapy program after surgery, achieved higher levels of knee extensor and flexor muscle strength after anterior cruciate ligament reconstructive surgery than those patients undergoing a traditional physical therapy program only after surgery.
\end{abstract}

Keywords: anterior cruciate ligament, intensive physical therapy, muscle strength.

\section{INTRODUCTION}

$\mathrm{T}$ he knee joint is the largest human joint; it has a complex anatomical and biomechanical structure. During the motion this joint not just absorbs force but it also transmits and distributes it to the reference points and allows movement (Escamilla et al., 2012).

During mechanical injuries the knee joint are often injured. Knee injuries take important place in musculoskeletal system injuries. Knee injuries account for $40.7 \%$ of all musculoskeletal injuries. The knee cruciate ligament injuries usually occur in 15 to 25 -year-old people, especially athletes
(Vitkus et al., 2007). Anterior cruciate ligament injuries are common for basketball, footbal players, gymnasts, grass hockey, handball, volleyball players, mountain skiers (Lind et al., 2009).

Anterior cruciate ligament (ACL) injuries cause instability, pain, which decrease physical activity and reduce the quality of life. Decreased strain for leg muscle leads to femoral muscle loss, then symptoms become apparent (Escamilla et al., 2012). Improper functioning of the anterior cruciate ligament of the knee develops deforming arthrosis (Ренстрёма, 2003). 
Anterior cruciate ligaments are injured 30 times more then posterior cruciate ligaments. In the United States anterior cruciate ligament injuries occur more than 95 thousand times each year. Every year about $65-75$ thousand anterior cruciate ligament reconstructive surgeries are performed. It is very important to determine the risk factors and develop prevention strategies (Vitkus et al., 2007).

In Lithuania about 950 anterior cruciate ligament injuries occur and 750 surgeries are performed every year. Most of the reconstructive surgeries are performed using arthroscopy technique. The knee joint is less damaged.

Physical therapy is very important in the treatment of anterior cruciate ligament, especially before surgery. Results of preoperative physical therapy influence better healing, better knee function recovery for patients after knee reconstruction surgery.

Physical therapy focuses on the safe physiological healing terms of reconstructed anterior cruciate ligament. Physical therapy returns the normal knee range of motion, muscle strength, balance and coordination more quickly and effectively (Hensler et al., 2012). A very important element for the effectiveness of physical therapy of athletes is specific movements for specific sport (Ренстрёма, 2003).

Research aim was to compare the effectiveness of intensive and traditional rehabilitation of the knee extensor and flexor muscle strength after the surgery for patients after anterior cruciate ligament reconstruction.

\section{RESEARCH METHODS}

Participants and Procedure. A total of 30 patients were enrolled in this study. The research was performed in the period of 2008-2010. Surgeries were performed in Sports Trauma and Arthroscopic Surgery Department of the Hospital of Lithuanian University of Health Sciences, and the Orthopedics and Traumatology Clinic. Rehabilitation was performed in Rehabilitation Clinic. All testing was carried out in the Lithuanian Academy of Physical Education, Laboratory of Human Motorics. The study included only those subjects who met the following criteria: 1) ACL reconstructive surgery was performed for the first time; 2) other knee ligaments, meniscus did not have injuries or reconstructive surgery; 3) non-operated leg did not have surgery or trauma; 4) there was no inflammation or poor general physical condition after surgery; 5) athletes were younger than 35 years old; 6) less than 3 months passed from injury to surgery.

Surgeries were carried out by the same surgeon, the same reconstruction method was applied, using the muscle tendon transplant (semitendinosus gracilis). The physical therapy was performed in Rehabilitation Clinic of the Hospital of Lithuanian University of Health Sciences.

The subjects were divided into two groups; each group involved 15 participants, randomly selected according to their birthday. Different physical therapy techniques were applied by different protocols. Intensive physical therapy was applied for the first group of participants. The second group received standard physical activity.

The first group consisted of 13 men and 2 women. Their age was $25.6 \pm 7.5$ years, height was $177 \pm 9 \mathrm{~cm}$, weight $-81 \pm 13.7 \mathrm{~kg}$. The second group consisted of 13 men and 2 women. Their age at the time of surgery was $27.4 \pm 7.1$ years, height $175 \pm 10 \mathrm{~cm}$ and weight $-78 \pm 11.4 \mathrm{~kg}$.

The participants completed the questionnaires, after the research aim was explained to them. Leg muscle strength was evaluated twice with "Biodex Medical System 3 PRO" independently of the physical therapy techniques: 1) the first testing was performed about 2 days before the anterior cruciate ligament reconstructive surgery; 2) the second testing - about 6 months after anterior cruciate ligament reconstructive surgery.

Research procedure and program. Leg muscle peak force was measured by three angular speeds $-30,180,300 \%$ s. All testing was performed using special equipment for testing and rehabilitation "Biodex Medical System 3 PRO" (Certified ISO 9001 EN 46001). During the test all participants were encouraged to use the greatest force to defeat equipment resistance by the angle of different speed. All testing was performed using isokinetic mode by protocol. First healthily leg was tested and later - the damaged one.

\section{The research protocol:}

1) Warming-up: veloergometer for 5 min with 50-60 Watt. Then stretching exercises for $10 \mathrm{~min}$.

2) Five minutes rest before the test. During that period of time participant's body postural adjustments were determined using a dynamometer.

3) Te participants took five pilot tests of the knee extension and flexion for the amplitude and free speed.

4) Testing of the healthy leg. Angular velocity values $30,180,300 \%$ sere taken. Muscle rest between the angular speed test was $60 \mathrm{~s}$. 
5) Then the damaged leg was tested.

Physical therapy program. After surgery physical therapy for participants was performed in the ward. The procedures continued at home. Both research groups received different physical therapy techniques.

Electrostimulation was applied for the group which received intensive physical therapy. The protocol is given in the Table. Electrostimulation was performed using "NeuroTrac SPORT XL“ equipment. Electrodes were fixed at the beginning of quadriceps muscle and in the end of the perpendicular to the muscle fibers.

To reduce post-operative pain and swelling, we applied cold procedures for both groups. Cryotherapy was performed immediately after surgery, 3-4 times a day. It took 15-20 minutes.

Physical therapy programs were based on other authors' recommendations.

Important limitations of physical activity:

1) Intensive physical therapy:

- Flexion: the knee flexion is limited to 90 degrees in the first week, in the second week it is limited to 110 degrees. Full range of motion of the knee flexion is achieved after a month.

- Extension: from the first day full knee extension range of motion after ACL surgery is allowed.

- Footing: from the first day after ACL surgery, using all body weight for the participants leg is allowed and elbow crutches are recommended at the begining for the safety of the paticipants.

- Stretching exercises.

2) Standard physical therapy:

- Flexion: the knee joint flexion is limited to 30 degrees for two weeks. From the third week the range of motion is increased to 90 degrees. The normal range of motion of the knee joint flexion is achieved after 7-8 weeks.

- Extension: after ACL surgery full extension range of motion is allowed.

- Footing: two weeks after surgery all participants could use their foot using half of their body weight (Elbow crutches are allowed).

- Stretching exercises: The exercises are performed to discomfort (tension, tightness and pain), 3-4 days a week.

Following the recommendations of G. S. Roi et al. (2006), C. Voigt et al. (2006), A. Vadala et al. (2007), H. J. Silvers et al. (2007), we created a standard physical therapy program for ACL injuries:

1) Before surgery we informed the participants about the preoperative and postoperative period, about the possible occurrence of bruising after reconstructive surgery.

2) After surgery we used the load gradually.

In the first phase (0-14 days) the aim was to walk or to elevate the leg in a standing position, using orthopedic brace while the leg was fully extended. We used soft orthopedic brace which kept the knee joint in the open position; isometric exercises (extended leg raising, quadriceps muscle strained), also in the first two weeks passive flexion and extension in the knee joint (range of motion to 30 degrees) was used. These movements were best performed in a standing position.

In the second phase (2-4 weeks) the aim of therapy was to restore knee flexion to 90 degrees. Muscle strengthening exercises of proprioception coordination exercises (climbing stairs), 2-3 times a day were used.

In the third phase (1-2 months) the aim of therapy was to achieve a full range of motion. Increased range of motion was used gradually; proprioception training continued; exercises in the pool and leg muscle strenthening exercises for 60 minutes were performed.

Table. The phase of the electrostimulation, frequency and duration of work

\begin{tabular}{|l|c|c|c|c|c|}
\hline \multicolumn{1}{|c|}{$\begin{array}{c}\text { Work/Duration of } \\
\text { work }\end{array}$} & $\begin{array}{c}\text { The first phase } \\
\mathbf{5} \text { min } \\
\text { (Warming-up) }\end{array}$ & $\begin{array}{c}\text { The second phase } \\
\mathbf{1 5} \mathbf{~ m i n} \\
\text { (continuous work) }\end{array}$ & $\begin{array}{c}\text { The third phase } \\
\mathbf{1 0} \text { min } \\
\text { (continuous work) }\end{array}$ & $\begin{array}{c}\text { The fourth phase } \\
\mathbf{1 5} \text { min } \\
\text { (continuous work) }\end{array}$ & $\begin{array}{c}\text { The fifth phase } \\
\mathbf{5} \text { min } \\
\text { (continuous work) }\end{array}$ \\
\hline $\begin{array}{l}\text { Frequency of muscle } \\
\text { work }\end{array}$ & $10 \mathrm{~Hz}$ & $20 \mathrm{~Hz}$ & $30 \mathrm{~Hz}$ & $20 \mathrm{~Hz}$ \\
\hline Impulse time & $250 \mu \mathrm{sz}$ & $300 \mu \mathrm{s}$ & $300 \mu \mathrm{s}$ & $3 \mathrm{~Hz}$ \\
\hline Frequency of the rest & - & $300 \mu \mathrm{s}$ & $3 \mathrm{~Hz}$ & $2.5 \mathrm{~s}$ \\
\hline Time of relaxation & - & $3 \mathrm{~Hz}$ & $2.5 \mathrm{~s}$ & - \\
\hline
\end{tabular}


In the fourth phase (2-4 months) the aim was to increase strength and endurance. Strength exercises with weights $(60 \mathrm{~min})$ and non-contact exercises were used. If there were no complaints, the loads were increased gradually.

In the fifth phase (4-12 months) the aim was return to specific sport training with the doctor's permition. Proprioception training was continued; then $70-80 \%$ of healthy isokinetic leg strength was achieved and training in special sport was allowed. Isokinetic exercises in full range of motion were allowed as well.

Following the recommendation of $\mathrm{M}$. Asik et al. (2007), G. S. Roi et al. (2006), D. K. Shelbourne et al. (2006), C. Voigt et al. (2006), we created intensive physical therapy protocol for ACL injuries.

1) before surgery we used functional and strength training; we informed the participants about preoperative and postoperative period and the possible occurrence of bruising after reconstructive surgery. The muscle training was carried out 4-5 times per week before surgery.

2) After surgery we used the load gradually.

In the first phase (0-14 days) the physical therapy aim was to reach the knee flexion up to 90 degrees. It was used to correct standing while the leg was fully extended; to walk or to elevate the leg in a standing position while leg was fully extended. Electrostimulation was performed on first day after the surgery (Table).

In the second phase (2-4 weeks) the aim was to reach a full range of motion in the knee joint. We used proprioception - coordination training exercises 2-3 times a day, muscle training and strengthening exercises and patela mobilization.

In the third phase (1-2 months) the aim was to reach a full range of motion on the knee joint. We used proprioception training, exercises in the pool, then we started exercises on a treadmill stacionary bike, muscle strenthening exercises for 60 min 3-4 times a week, in order to reach physical activity as it was before injury.

In the fourth phase (2-4 months) the aim was sport specific exercises. It was used diferent leg movement exercises for 30-60 min 3-4 times a week, muscle strength and endurance exercises (60 min), flexibility exercises, and non-contact exercises. If there was no complaining, the loads were increased gradually.

In the fifth phase (4-6 months) the aim of physical therapy was to go back to sport with the doctor's permition. Proprioception training was continued, as well as running on treadmill with increasing loads, after achieving $70-80 \%$ of healthy isokinetic leg strength, training in special sport was allowed. Isokinetic exercises in full range of motion were allowed as well.

Statistical analyses. The research data were processed using Microsoft Excel 2007 and Statistical Package for the Social Sciences (SPSS). The data are reported as group mean values \pm standard deviation (SD).

Hypothesis of normal distribution of test characteristics were tested using ShapirWilk test. Comparing the quantity data that is distributed under the normal distribution we used nonparametric rank analysis. For two dependent samples, checking the reliability of the differences, we used Wilcoxon criterion. For the reliability of differences for independent samples we used Mann-Whitney criterion.

The data were statistically significant at $\mathrm{p}<0.05$.

\section{RESEARCH RESULTS}

Leg muscle strength results using different physical therapy before ACL reconstructive surgery. The first participant group had physical therapy procedures before surgery. The research results showed that the first group participants' muscle strength was bigger than that in the second group for the injured leg at different angular velocity.

The research results showed that extension muscle strength depended on the speed of muscle contraction and physical therapy technique.

Maximum muscular extension strength for healthy and injured leg before ACL reconstruction surgery. As we see in Figure 1, the participants reached the maximum strength at the lowest angular velocity $(30 \%)$. The healthy leg maximum muscular extension strength was bigger than the injured leg for both groups at all angular velocities $(\mathrm{p}<0.05)$.

Figure 1 shows that between injured sides there was the greatest improvement in the intensive physical therapy group compared to standard physical therapy group, when the angular velocities were $30 \mathrm{~s}$ and $180 \% \mathrm{~s}(\mathrm{p}<0.05)$. At the angular velocity of $300 \%$ so significant difference $(p>0.05)$ was observed. 
The results showed that different physical therapy did not have any influence on the healthy $\operatorname{leg}(\mathrm{p}>0.05)$.

There was a trend in the leg extension at the knee joint, that with the increase of the speed of muscle contraction, muscle contraction strength decrease and the differences between these factors decreased, too.

Muscular flexion strength for healthy and injured leg before ACL reconstruction surgery using different physical therapy techniques showed that participants reached the maximum strength at the lowest angular velocity $(30 \% \mathrm{~s})$. For both groups healthy leg muscular flexion strength was greater than the injured leg muscle strength at different angular velocities (Figure 2).

Using different physical therapy for all angular velocities there were significant differences between healthy and injured legs $(\mathrm{p}<0.05)$.

The participants who applied the intensive physical therapy showed bigger muscle contraction strength in injured leg, compared to standard physical therapy group, for all muscle contraction speed $(\mathrm{p}>0.05)$.

During the knee flexion for healthy leg at all angular velocities, the differences between groups were not significant $(\mathrm{p}>0.05)$.

There was a trend in the leg flexion in the knee joint, that with the increase of speed of muscle contraction, muscle contraction strength was reduced and the differences between these factors decreased.
Leg muscle strength results using different physical therapy after ACL reconstructive surgery. The second test was performed 6 months after ACL reconstructive surgery. For 6 months different physical therapy techniques were applied.

Figure 3 shows that the participants reached the maximum strength at the lowest angular velocity $(30 \%)$. The result showed, that in both groups the healthy leg muscle extension strength was greater than that of the operated leg muscle strength at all angular velocities $(\mathrm{p}<0.05)$ except for $300 \%$ angular velocity in intensive physical therapy group $(\mathrm{p}>0.05)$.

The participants in intensive physical therapy group showed bigger muscle strength improvement for the operated leg than participants who received standard physical therapy $(\mathrm{p}<0.05)$.

There was a trend in the leg flexion in the knee joint, that with the increase in speed of muscle contraction, muscle contraction strength is reduced and the differences between these factors decreased.

Six months after ACL reconstructive surgery operated and healthy leg flexion muscle strength in both groups participants reached the maximum strength at the lowest angular velocity $(30 \%)$ (Figure 4).

The participants who received the intensive physical therapy showed bigger muscle contraction strength in the operated leg, compared to the standard physical therapy group, for all different angular velocities $(\mathrm{p}>0.05)$.
Figure 1. Healthy and injured leg, different physical therapy techniques, maximum muscular extension strength at different speed of muscle contraction before surgery

Note. Statistically significant: - - healthy and injured leg, standard physical therapy. $(\mathrm{p}<0.05) ; \diamond-$ healthy and injured leg, intensive physical therapy. $(\mathrm{p}<0.05)$; * injured leg, standard and intensive physical therapy $(\mathrm{p}<0.05) ; ¥$ - healthy leg, standard and intensive physical therapy $(\mathrm{p}<0.05)$.

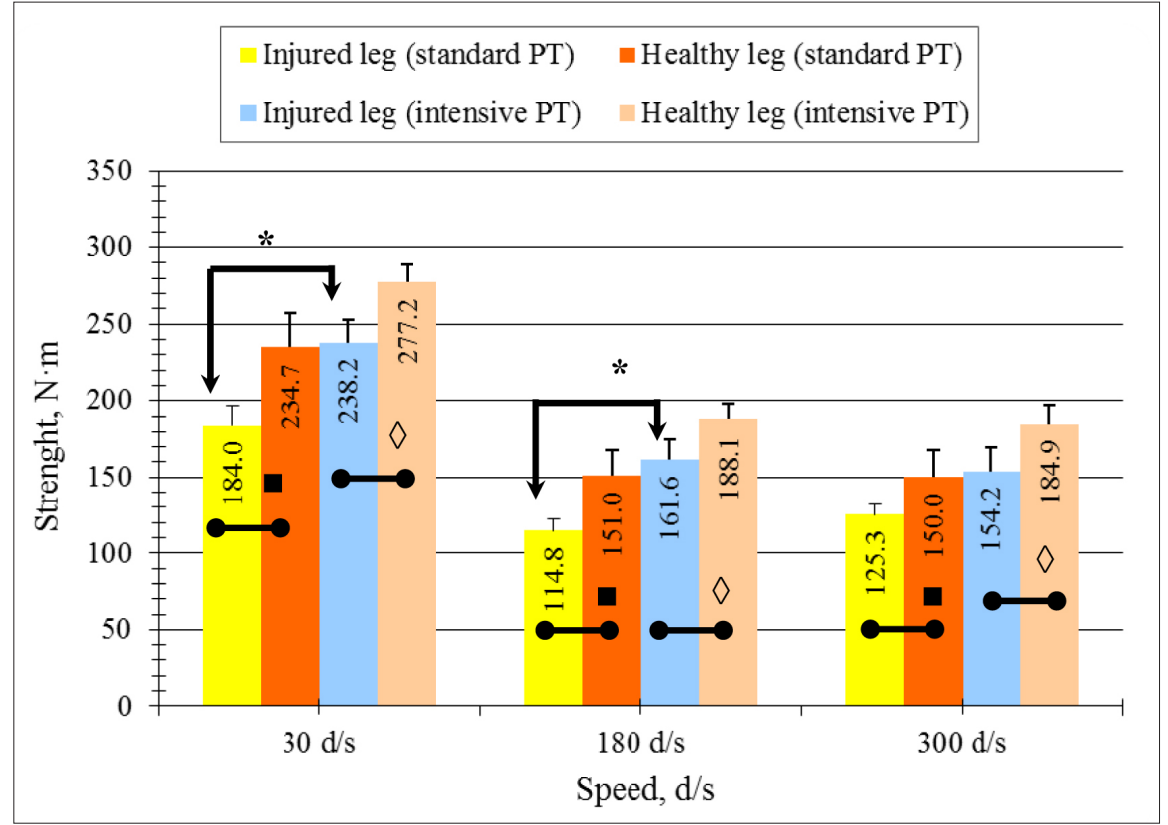



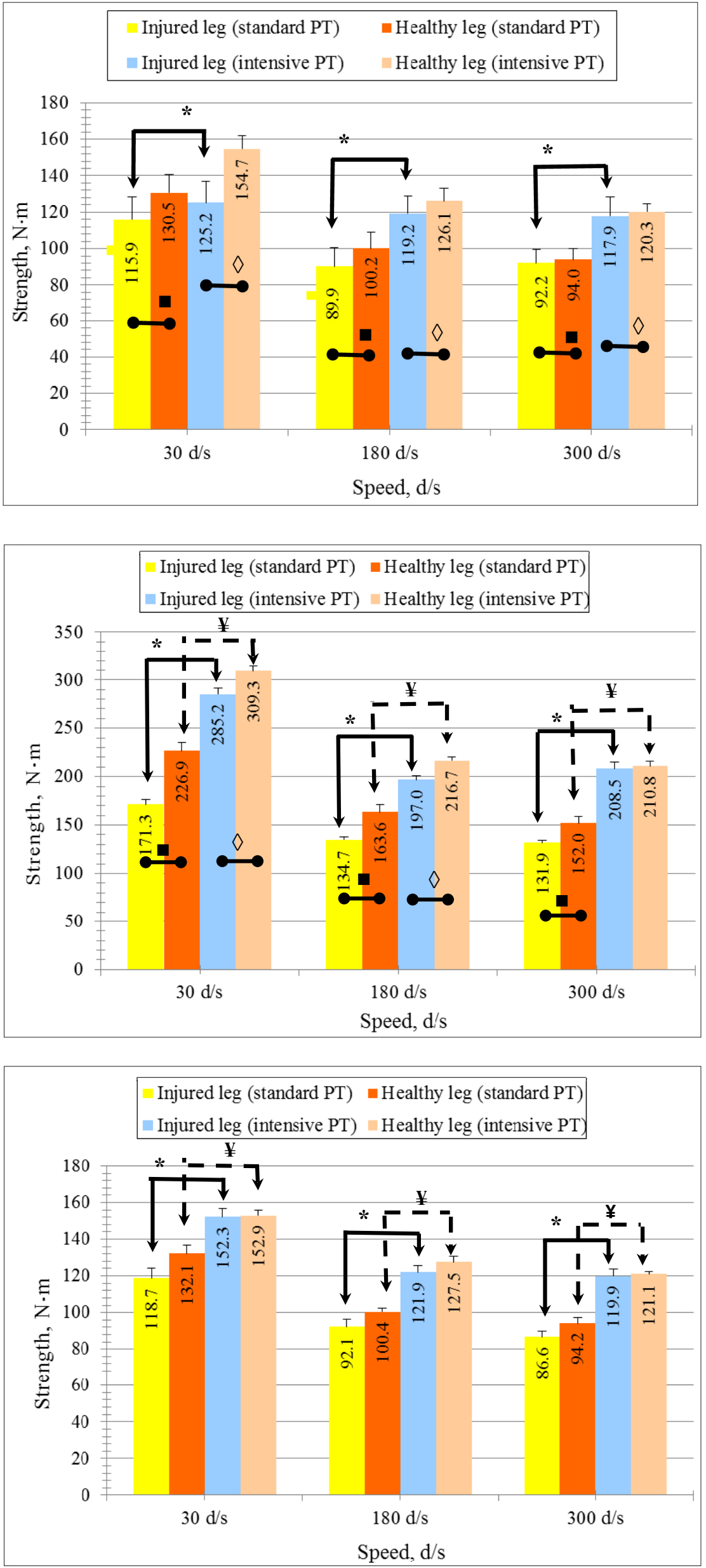

Figure 2. Healthy and injured leg, different physical therapy techniques, maximum muscular flexion strength at different speed of muscle contraction, before surgery

Note. Statistically significant: - - healthy and injured leg, standard physical therapy. $(\mathrm{p}<0.05) ; \diamond-$ healthy and injured leg, intensive physical therapy. $(\mathrm{p}<0.05)$; * injured leg, standard and intensive physical therapy $(\mathrm{p}<0.05)$; $¥$ - healthy leg, standard and intensive physical therapy $(\mathrm{p}<0.05$ ).

Figure 3. Healthy and injured leg, different physical therapy techniques, maximum muscular extension strength at different speed of muscle contraction, after surgery

Note. Statistically significant: - - healthy and injured leg, standard physical therapy. $(\mathrm{p}<0.05) ; \diamond-$ healthy and injured leg, intensive physical therapy. $(\mathrm{p}<0.05)$; * injured leg, standard and intensive physical therapy ( $\mathrm{p}<0.05)$; $¥$ - healthy leg, standard and intensive physical therapy $(\mathrm{p}<0.05)$.

Figure 4. Healthy and injured leg, different physical therapy techniques, maximum muscular flexion strength at different speed of muscle contraction, after surgery

Note. Statistically significant: - - healthy and injured leg, standard physical therapy. $(\mathrm{p}<0.05) ; \diamond-$ healthy and injured leg, intensive physical therapy. $(\mathrm{p}<0.05)$; *injured leg, standard and intensive physical therapy ( $<<0.05)$; $¥$ - healthy leg, standard and intensive physical therapy $(\mathrm{p}<0.05)$. 


\section{DISCUSSION}

Scientific publications analyze the effectiveness of physical therapy after ACL reconstructive surgery. In recent years, one of the most popular and reliable methods to assess the effectiveness of physical therapy has been isokinetic dynamometry (Gobbi, Francisco, 2006; Hiraoka et al., 2008; Almqvist el al., 2009). While analyzing Lithuanian and foreign literature, we did not find evidence about physical therapy effectiveness before and after ACL reconstructive surgery. Thus, our work is different from the earlier research work.

The results obtained during the study showed that the muscle strength was developed depending on the angular velocity. This is particularly evident in both groups in healthy and injured leg extensor muscle strength. Our results coincide with the ones obtained by other authors (Almqvist et al., 2009). The higher the angular speed in leg extension, the lower the maximum muscle strenght is developed.

Comparing healthy and injuried leg after ACL reconstuctive surgery, we see that extensor muscle strength is bigger in intensive physical therapy group than in standard physical therapy group. Our research results coincide with those of other authors who state that quadriceps femoris muscle strength of the operated leg is lower than that of healthy leg independently what physical therapy is applied (Seto et al., 1998; Hoffman et al., 1999). Researcher's results showed that after ACL reconstructive surgery extensor muscle strength fully recovered in 6-12 months after surgery using standard physical therapy (Feller et al., 2004; De Jong et al., 2007), but using intensive physical therapy extensor muscle strength fully recovered after 4-6 months (Roi et al., 2006; Heijne, Werner, 2007). Similar results were obtained by Japanese researchers, who studied participants after ACL surgeries and found that for $90 \%$ of participants quadriceps muscle strength fully recovered 2 years after surgery (Kobayashi et al., 2004). It should be noted that standard physical therapy duration is few months longer than intensive physical therapy duration. Our patients were tested after 6 months after ACL reconstructive surgery. We can assume that after 9 months or after one year muscle strength would be even more similar.

After 6 months after ACL reconstruction surgery in both groups the injured leg reached the healthy leg indicators. However, we noticed the difference between participants in both groups after 6 months after surgery.

According to the majority of authors, after the surgery a patient can resume intensive physical activity, when the difference in muscle strength between the operated lower extremity and another extremity is not greater than $10-15 \%$ (Keays et al., 2000; Hiemstra et al., 2004).

The participants who received physical therapy before surgery, electrostimulation and intensive physical therapy program after surgery, achieved higher levels of knee extensor and flexor muscle strength after anterior cruciate ligament reconstructive surgery than those patients undergoing a traditional physical therapy program only after surgery.

\section{CONCLUSIONS AND PERSPECTIVES}

The patients undergoing an intensive physical therapy achieved higher levels of knee extensor and flexor muscle strength than those patients undergoing a traditional rehabilitation program. We recommend to use preoperative physical therapy; after anterior cruciate ligament reconstruction surgery electrostimulation and water physical tehrapy should be used. 


\section{REFERENCES}

Almqvist, K. F., Willaert, P., De Brabandere, S., Criel, K., Verdonk, R. (2009). A long-term study of anterior cruciate ligament allograft reconstruction. Knee Surgery, Sports Traumatology, Arthroscopy, 17, 8 $18-822$.

Asik, M., Sen, C., Tuncay, I. et al. (2007). The midto long-term results of the anterior cruciate ligament reconstruction with hamstring tendons using Transfix technique. Knee Surgery Sports Traumatology, Arthroscopy, 15, 965-972.

Escamilla, R. F., Macleod, T. D., Wilk, K. E., Paulos, L., Andrews, J. R. (2012). Anterior cruciate ligament strain and tensile forces for weight-bearing and non-weightbearing exercises: A guide to exercise selection. The Journal of Orthopedic and Sports Physical Therapy, 42 (3), 208-220.

Feller, J., Webster, K., Taylor, N. et al. (2004). Effect of physiotherapy attendance on outcome after anterior cruciate ligament reconstruction: A pilot study. British Journal of Sports Medicine, 38 (1), 74-77.

Gobbi, A., Francisco, R. (2006). Factors affecting return to sports after anterior cruciate ligament reconstruction with patellar tendon and hamstring graft: A prospective clinical investigation. Knee Surgery, Sports Traumatology, Arthroscopy, 14, 1021-1028.

Heijne, A., Werner, S. (2007). Early versus late start of open kinetic chain quadriceps exercises after ACL reconstruction with patellar tendon or hamstring grafts: A prospective randomized outcome study. Knee Surgery, Sports Traumatology, Arthroscopy, 15, 402-414.

Hensler, D., Van Eck, C. F., Fu, F. H., Irrgang, J. J. (2012). Anatomic anterior cruciate ligament reconstruction utilizing the double-bundle technique. The Journal of Orthopedic and Sports Physical Therapy, 42 (3), 184-195.

Hiemstra, L. A., Webber, S., MacDonald, P. B., Kriellaars, D. J. (2004). Hamstring and quadriceps strength balance in normal and hamstring anterior cruciate ligament-reconstructed subjects. Clinical Journal of Sport Medicine, 14 (5), 274-280.

Hiraoka, H., Yashiki, M., Sakai, H. (2008). Contributory factors to the results of gravity-assisted pivot-shift test for anterior cruciate ligament injury: The significance of muscle torque around the knee. Knee Surgery, Sports Traumatology, Arthroscopy, 16, 279-285.

Hoffman, M., Schrander, J., Koceja, D. (1999). An investigation of postural control in postoperative anterior cruciate ligament. Journal of Athletic Training, 34, 130-136.
De Jong, S., Van Caspel, M., Van Haeff, M. et al. (2007). Functional assessment and muscle strength before and after reconstruction of chronic anterior cruciate ligament lesions. Arthroscopy: The Journal of Arthroscopic \& Related Surgery, 23 (1), 2-5.

Keays, S. L., Bullock-Saxton, J., Keays, A. C. (2000). Strength and function before and after anterior cruciate ligament reconstruction. Clinical Orthopedics and Related Research, 373, 174-183.

Kobayashi, A., Higuchi, H., Terauchi, M. et al. (2004). Muscle performance after anterior cruciate ligament reconstruction. International Orthopedics, 28 (1), $48-51$.

Lind, M., Menhert, F., Pedersen, A. B. (2009). The first results from the Danish ACL reconstruction registry: Epidemiologic and 2 year follow-up results from 5,818 knee ligament reconstructions. Knee Surgery, Sports Traumatology, Arthroscopy, 17, 117-124.

Roi, G. S., Nanni, G., Tencone, F. (2006). Time to return to professional soccer matches after ACL reconstruction. Sport Sciences for Health, 1, 142-145.

Seto, J. L., Orofino, A. S., Morisey, M. C. et al. (1998). Assessment of quadriceps/hamstrings strength, knee ligament stability, functional and sports activity levels five years after anterior cruciate ligament reconstruction. American Journal of Sports Medicine, 16, 170-180.

Shelbourne, K. D., Lawrance, S., Noy, R. (2006). Anterior Knee Pain and Patellar Instability. London: Springer-Verlag. P. 283-293.

Silvers, H. J., Mandelbaum, B. R. (2007). Prevention of anterior cruciate ligament injury in the female athlete. British Journal of Sports Medicine, 41, 52-59.

Vadala, A., Iorio, R., De Carli, A. et al. (2007). The effect of accelerated, brace free, rehabilitation on bone tunnel enlargement after ACL reconstruction using hamstring tendons: A CT study. Knee Surgery, Sports Traumatology, Arthroscopy, 15, 365-371.

Vitkus, L., Kalesinskas, J., Belickas, J. et al. (2007). Kineziterapijos efektyvumas po skirtingu priekinio kryžminio raiščio rekonstrukcinių operacijų. Visuomenès sveikata, 1 (36), 46-53.

Voigt, C., Schönaich, M., Lill, H. (2006). Anterior cruciate ligament reconstruction: State of the art. European Journal of Trauma, 32, 332-339.

Ренстрёма, П. А. Ф. Х. (2003). Спортивныле травмыл: клиническая практика предупреждения и лечения). Киев: Олимпийская литература. С. 102-139. 


\title{
KINEZITERAPIJOS VEIKSMINGUMO IVERTINIMAS BLAUZDOS RAUMENŲ JËGAI PO KELIO SĄNARIO PRIEKINIO KRYŽMINIO RAIŠČIO REKONSTRUKCINĖS OPERACIJOS
}

\author{
Kęstutis Radžiūnas ${ }^{1}$, Vytenis Trumpickas ${ }^{2}$, Jonas Poderys ${ }^{\mathbf{3}}$ \\ Lietuvos sveikatos moksly universitetas, Medicinos akademija ${ }^{1}$, Kaunas, Lietuva \\ Lietuvos sveikatos moksl universiteto ligonine Kauno klinikos ${ }^{2}$, Kaunas, Lietuva \\ Lietuvos kūno kultūros akademija ${ }^{3}$ Kaunas, Lietuva
}

\section{SANTRAUKA}

Tyrimo pagrindimas ir hipoteze. Kompleksinio gydymo metu po judamojo aparato traumų kineziterapijos procedūrų tikslas - padèti ligoniams greičiau atgauti buvusį fizinį aktyvuma. Šio tyrimo hipotezè buvo tokia: taikant intensyvios kineziterapijos programą ligonių po priekinio kryžminio raiščio rekonstrukcinės operacijos blauzdos raumenu jègos atsigavimo tempai bus greitesni.

Tikslas - palyginti intensyvios ir iprastinès kineziterapijos veiksmingumą, blauzdos tiesiamujų ir lenkiamuju raumenų jègai po priekinio kryžminio raiščio rekonstrukcinès operacijos.

Metodai. Buvo tiriama 30 Lietuvos sveikatos mokslų universiteto Kauno kliniku ligonių. Skirtingos kineziterapijos programos taikytos pagal atskirus protokolus. Buvo naudojamas šis tyrimo metodas: blauzdos raumenu jëga vertinama naudojant „Biodex Medical System 3 PRO“ aparatūrą - lenkiant ir tiesiant koją per kelio sąnarị.

Rezultatai. Nustatyta, kad tiriamieji, kuriems buvo taikyta intensyvi kineziterapijos programa, išugdè didesnę blauzdos tiesiamujų ir lenkiamujų raumenu jègą nei tie, kuriems buvo taikyta iprastinè kineziterapijos programa. Taikant intensyvią kineziterapijos programą, blauzdos tiesiamieji ir lenkiamieji raumenys atsigauna greičiau nei taikant iprastinę kineziterapijos programą.

Aptarimas ir išvados. Tiriamujų, kuriems buvo taikyta priešoperacinė kineziterapija, elektrostimuliacija ir intensyvi pooperacinè kineziterapijos programa, blauzdos tiesiamujų ir lenkiamujų raumenų jèga po priekinio kryžminio raiščio rekonstrukcinès operacijos yra didesnè nei tų, kuriems buvo taikoma iprastinè kineziterapijos programa tik pooperaciniu laikotarpiu.

Raktažodžiai: priekinis kryžminis raištis, intensyvi kineziterapijos programa, raumenu jẻga. 